\title{
Agronomic Management Strategies to Reduce the Yield Loss Associated with Spring Harvested Corn in Ontario
}

\author{
Kris J. Mahoney ${ }^{1}$, Jonathan H. Klapwyk², Greg A. Stewart ${ }^{3}$, W. Scott Jay ${ }^{1}$, David C. Hooker ${ }^{1}$ \\ ${ }^{1}$ University of Guelph, Ridgetown Campus, Ridgetown, Canada \\ ${ }^{2}$ Independent Author, Elora, Canada \\ ${ }^{3}$ Ontario Ministry of Agriculture, Food and Rural Affairs, Guelph, Canada \\ Email: kmahoney@uoguelph.ca
}

Received 21 January 2015; accepted 10 February 2015; published 15 February 2015

Copyright @ 2015 by authors and Scientific Research Publishing Inc.

This work is licensed under the Creative Commons Attribution International License (CC BY). http://creativecommons.org/licenses/by/4.0/

(c) (i) Open Access

\section{Abstract}

Some growers in northern corn (Zea mays L.) producing regions forgo the typical autumn harvest for various reasons, but not without the risk of significant yield loss. Therefore, strategies are needed for managing the risks to yield when harvesting corn in spring. Field experiments, with various management strategies, were initiated in Ontario, Canada near Belmont and Ridgetown in 2009 and near Belmont, Ridgetown, and Lucan in 2010. Management strategies investigated the use of hybrids with a range in maturity, the use of standard and reduced plant populations, and the use of a foliar fungicide applied around tasseling. The parameters examined were stay-green in autumn, lodging in spring, and grain yield, moisture, and test weight of corn harvested in autumn and spring. Standard corn production practices consist of using a full-season hybrid planted at 80,000 plants $\cdot \mathrm{ha}^{-1}$ with no late-season fungicide application; however, if over-wintered at Belmont, corn managed using these practices resulted in a $23.1 \%$ yield loss (12.1 vs $\left.9.3 \mathrm{Mg} \cdot \mathrm{ha}^{-1}\right)$ averaged across years when the crop was harvested in the spring. An overwintering management strategy for corn was identified, which consisted of planting at a reduced plant population $(60,000$ plants·ha ${ }^{-1}$ ) and spraying the crop with QUILT ${ }^{\circledR}$ (azoxystrobin + propiconazole at $200 \mathrm{~g} \mathrm{a.i.}^{-1} \mathrm{~h}^{-1}$ ) at the VT to R1 growth stage. Averaged across all hybrids, this strategy minimized yield losses through improvements on corn standability with only a $3.5 \%$ yield loss at Ridgetown and a $13.2 \%$ yield loss at Belmont. Furthermore, grain test weights for corn with the overwintering strategy were similar to or greater than corn overwintered with the standard production practice. However, weather conditions have the potential to overwhelm any management strategy. In spite of the favorable data indicating reduced risks with a spring harvest, lodging was still higher than expected and yield losses would likely be unacceptable for most growers to make a spring corn harvest a widely accepted practice, unless autumn grain moistures are extremely high, drying charges

*Corresponding author.

How to cite this paper: Mahoney, K.J., Klapwyk, J.H., Stewart, G.A., Jay, W.S. and Hooker, D.C. (2015) Agronomic Management Strategies to Reduce the Yield Loss Associated with Spring Harvested Corn in Ontario. American Journal of Plant Sciences, 6, 372-384. http://dx.doi.org/10.4236/ajps.2015.62043 
are high, and if stalk strength going into the winter was exceptional.

Keywords

Fungicide, Hybrid, Plant Population, Lodging, Stay-Green, Yield

\section{Introduction}

Growers in the northern corn (Zea mays L.) producing regions of North America can encounter various management challenges. While selecting full-season or later maturing corn hybrids can maximize yield [1]-[3], later maturity hybrids can have high grain moisture content at harvest (more than $30 \%$ to 35\%), contributing to increased drying costs [4] and low grain test weights. Increased autumn precipitation, a trend observed in eastern Canada and the northeastern United States [5] [6], can also delay harvest and could contribute to high grain moisture content. As a result, growers have devised hybrid selection and grain drying strategies in an attempt to maximize economic returns with an acceptable level of risk. However, if soil moisture conditions make a timely harvest unfeasible [7] [8] or if volatility in the corn market and/or energy prices makes drying high-moisture corn cost prohibitive, growers may need an alternative strategy to minimize risk. A practice used by some growers is to forgo the typical autumn harvest, allow the corn to dry down in the field over winter, and harvest the crop in spring when the harvested grain does not incur drying costs. While alleviating the added expense of drying high-moisture corn and storing dry corn over winter, there can be increased risk of lodging over winter, impacting crop harvestability and grain yield [9].

Management practices currently exist which can improve corn standabilty (i.e., stalk or root lodging). For example, growers can manage lodging by selecting hybrids rated for superior stalk strength and by selecting later maturing hybrids. In an Ohio study, standability improved with a later maturing hybrid with an above average stalk strength rating during delayed autumn harvests compared to an earlier maturity hybrid with a similar stalk strength rating [7]. In the absence of concerns with the high grain moisture content associated with later maturing hybrids, the selection of a full-season or later maturing hybrid could be a management strategy to capitalize on improved standability that would accompany a decision to forgo the typical autumn harvest. Furthermore, growers can also alter seeding rates to manage lodging since the relationship between increased plant densities and increased lodging is well documented [10]-[15]. Due to concerns with lodging from overwintering corn, a reduction in plant density could improve standability for a spring harvest. For example, stalk lodging during a harvest delayed until early to mid-December [7] or late March [8] was considerably reduced when using a low plant density (i.e., 59,000 plants ha $^{-1}$ ) compared to using higher plant densities. Lastly, foliar fungicides applied around tasseling (e.g., VT to R2 growth stage) have been shown to delay leaf senescence and improve stalk health [16] [17], which could contribute to improved standability.

Very limited research has been performed on managing corn with the intent of overwintering for a spring harvest. Wisconsin data from 2000 and 2001 indicated that yield losses during a spring harvest can vary widely with $38 \%$ to $65 \%$ yield loss during a winter with heavy snow cover and only $7 \%$ to $10 \%$ yield loss in a winter with little snow cover [9]. However, since that data were reported, newer hybrid trait technologies, which have become adopted extensively [18]-[20], could have the potential to also improve corn standability over the winter. For example, Bt (Bacillus thuringiensis) traits for various insect pest resistance, which have been shown to reduce stalk and root lodging [11] [21]-[24], are commonly stacked in hybrids to include herbicide resistance. Use of these highly resistant hybrids [18] may reduce or eliminate the use of herbicides with more injurious modes of action (e.g., phenoxy or synthetic auxin herbicides) that may weaken stalks and increase lodging [25] and reduce corn yield [26]. When coupled with genetics for improved stalk strength, the adoption of hybrids with stacked resistance traits might improve the likelihood of successfully overwintering corn for a spring harvest. Unfortunately, management recommendations developed from research trials do not exist for minimizing the risks associated with harvesting corn in spring. However, management strategies for spring harvesting corn could be developed using technological innovations that are currently available to corn growers. Therefore, the objectives of this study were to: 1) determine the effects of hybrid maturity, plant population, foliar fungicide application, and harvest timing on grain yield and standability, and 2) identify potential management opportunities for overwintering corn. 


\section{Materials and Methods}

\subsection{Study Establishment}

Field experiments were initiated in 2009 and 2010 on five separate locations in southern Ontario, Canada. Experiments were installed on two farm fields near Belmont $\left(42^{\circ} 87^{\prime} \mathrm{N}, 81^{\circ} 07^{\prime} \mathrm{W}\right)$ and Ridgetown, ON $\left(42^{\circ} 46^{\prime} \mathrm{N}\right.$, $\left.81^{\circ} 87^{\prime} \mathrm{W}\right)$ in 2009 , and on three other farm fields near Belmont $\left(42^{\circ} 87^{\prime} \mathrm{N}, 81^{\circ} 08^{\prime} \mathrm{W}\right)$, Ridgetown $\left(42^{\circ} 46^{\prime} \mathrm{N}\right.$ $\left.81^{\circ} 89^{\prime} \mathrm{W}\right)$, and Lucan, $\mathrm{ON}\left(43^{\circ} 20^{\prime} \mathrm{N}, 81^{\circ} 40^{\prime} \mathrm{W}\right)$ in 2010 . These locations were selected to not only represent major corn growing areas of the province, but to test treatments in contrasting winter environments. For example, winters at Ridgetown tend to be less harsh (e.g., moderate temperatures with less snow) than at Belmont. Compared to Belmont and Ridgetown, Lucan usually receives more snow because it is situated in the "snowbelt" region of southwest Ontario, which is leeward of Lake Huron. At each location, the treatments were arranged in a split-plot design with three splits and replicated four times. The main plot factor was harvest timing (autumn or spring), the first split was plant population $\left(60,000\right.$ or 80,000 plants·ha ${ }^{-1}$ ), the second split was QUILT ${ }^{\circledR}$ (azoxystrobin + propiconazole) foliar fungicide ( 0 or $200 \mathrm{~g}$ a.i. $\mathrm{ha}^{-1}$ ) applied at the VT to R1 growth stage, and the third split included three corn hybrids with different maturities. The hybrids that were selected for each location covered a range of maturity: early, full-season, and late (approximately 100 Crop Heat Units [27] later than the full-season). All hybrids exhibited good yield potential, standability, and stacked resistance traits (Table 1). The corn was seeded into rows spaced $0.75-\mathrm{m}$ apart to create experimental units 4 rows wide by $35-\mathrm{m}$ long. A buffer strip of 4 rows was used between each foliar fungicide split to minimize interference from the sprayer at tasseling. The experiments were designed to mimic farm field-scale environments by reducing field-edge effects from wind and snow. For example, an unharvested border of at least 12 rows was maintained around the experimental area at each field location, and an additional 4 rows of border were left unharvested around the overwintered corn. Within the unharvested border rows, 6 rows were harvested for trapping blowing snow during the winter.

Fields at all locations were planted at an optimal timing in early May of each year. Both fields near Belmont followed winter wheat underseeded to red clover; these fields were moldboard plowed in the autumn and cultivated twice in the spring for seedbed preparation. The previous crop for the fields near Ridgetown was soybean and the seedbed was prepared by cultivating twice in the spring. At the Lucan site, the previous crop was wheat and the field was moldboard plowed in the previous fall and received two passes with a cultivator in the spring. Soil tests were in the "medium" range for both phosphorus and potassium with a pH around 7 at each field location. A liquid starter pop-up fertilizer (6-24-6) was applied in-furrow at $56 \mathrm{~L} \cdot \mathrm{ha}^{-1}$ during both years at Belmont and 8-32-16 was applied at $150 \mathrm{~kg} \cdot \mathrm{ha}^{-1}$ in a band $5 \mathrm{~cm}$ to the side and $5 \mathrm{~cm}$ below the seed at Ridgetown during both years and at Lucan. Nitrogen was applied preplant or sidedress as 28-0-0 to achieve approximately $150 \mathrm{~kg}$ $\mathrm{N} \mathrm{ha}{ }^{-1}$ total in all fields. Weeds were controlled using recommended preplant incorporated and post emergence herbicide applications [28]. The fungicide treatment was applied when the latest hybrid reached VT growth

Table 1. Maturity and resistance characteristics of corn cultivars used in harvest timing experiments initiated in 2009 and 2010 at three locations in Ontario, Canada.

\begin{tabular}{|c|c|c|c|c|c|}
\hline Location & $\begin{array}{l}\text { Adapted } \\
\text { maturity }\end{array}$ & Cultivar & $\begin{array}{l}\text { Crop Heat Unit } \\
\text { rating }\end{array}$ & $\begin{array}{c}\text { Comparative } \\
\text { Relative Maturity }\end{array}$ & Resistance traits ${ }^{\mathrm{a}}$ \\
\hline & & & & d & \\
\hline \multirow[t]{3}{*}{ Belmont/Lucan } & Early & Pioneer 38M60 & 2800 & 94 & RR, ECB, CRW \\
\hline & Full & Maizex MZ 3969CBR & 2975 & 98 & RR, ECB, CRW \\
\hline & Late & Maizex MZ 4433HX/RR & 3100 & 103 & RR, LL, ECB \\
\hline \multirow[t]{3}{*}{ Ridgetown } & Early & Maizex MZ 4433HX/RR & 3100 & 103 & RR, LL, ECB \\
\hline & Full & Pioneer 35F44 & 3150 & 105 & RR, ECB, CRW \\
\hline & Late & Pioneer 34P89 & 3400 & 111 & LL, ECB \\
\hline
\end{tabular}

${ }^{\mathrm{a} R R}$, glyphosate resistance; LL, glufosinate resistance; ECB, European corn borer (Ostrinia nubilalis) resistance; and CRW, corn rootworm (Diabrotica spp.) resistance. 
stage using a commercial ground sprayer calibrated to deliver $190 \mathrm{~L} \cdot \mathrm{ha}^{-1}$ of solution through TeeJet 11004 nozzles (Spraying Systems Co., Glendale Heights, IL) spaced $0.5 \mathrm{~m}$ apart on a boom height-adjusted to spray over the tassels of the tallest hybrid. For the autumn harvest treatments, the main plots were harvested at a "typical" timing in October, and the spring timing was delayed until May 2010 and early June in 2011 when soil conditions could support the combine harvester.

\subsection{Data Collection and Analysis}

Stay-green was estimated visually as the percentage of the total leaf area remaining green in all plots in late September. In the spring, the lodging percentage was calculated by recording the number of stalks lodged by more than $45^{\circ}$ or broken below the ear found within three, 5-m lengths of the two center rows of all overwintered plots. Regardless of the harvest timing, corn was harvested from the middle two rows of each four-rowplot. Grain yields, grain moistures, and test weights were measured on small-plot combines equipped with Harvest Master Grain Gage Classic grain measurement systems (Juniper Systems, Inc., Logan, UT).

All data were analyzed using PROC MIXED (SAS Ver. 9.2, SAS Institute Inc., Cary, NC). Treatment effects were similar across years within each of the Belmont and Ridgetown locations $(P>0.25)$, but the treatment responses were different between Belmont and Ridgetown; therefore, years within each location were combined and the locations were analyzed separately in the final analysis. In this analysis, the fixed effects included harvest timing, plant population, fungicide, hybrid, and all of their interactions. The random effects included replication $\times$ harvest timing within year, replication $\times$ harvest timing $\times$ population within year, and replication $\times$ harvest timing $\times$ population $\times$ fungicide within year. Significance of fixed effects was tested using an F-test and random effects were tested using a Z-test of the variance estimate. PROC UNIVARIATE in SAS was used to test data for normality and homogeneity of variance. For grain yield, residual variances were different across harvest timing and year at Belmont and Ridgetown, which violated an assumption of ANOVA. Thus, these heterogeneous variances were modeled in PROC MIXED using the repeated statement with group $=$ year $\times$ harvest timing. Satterthwaite's approximation was used to estimate degrees of freedom. Residuals for grain moisture and test weight data were normalized using a transformation $\left[(n+0.1)^{0.5}\right]$ before analysis; means were backtransformed for presentation purposes. No transformations were necessary for other parameters. The sums of squares for interactions were partitioned across harvest timing using the SLICE option in PROC MIXED [29]. Means were separated within each slice using Fisher's Protected LSD at $P=0.05$.

\section{Results and Discussion}

Four out of the five field locations (Belmont and Ridgetown, initiated in 2009 and 2010) were harvested in the following spring. Data from the Lucan location were discarded because nearly $100 \%$ of the corn plants left to overwinter were pulled to the ground due to excessive snow accumulation. The Lucan experiment site was located approximately $20 \mathrm{~km}$ north of the London, ON weather station (Table 2) and typically receives twice as much snow from November to January due to enhanced lake-effect precipitation from Lake Huron. In comparison, the overwintering conditions in the fields near Belmont (approximately $15 \mathrm{~km}$ south of London) were less severe than at Lucan, but more severe than what occurred near Ridgetown. Ridgetown is approximately $80 \mathrm{~km}$ southwest from London and typically receives half as much snow as London (Table 2). In the current study, the main effects of harvest timing, plant population, fungicide application, and hybrid selection on grain yield tended to be highly significant $(P<0.001$, Table 3$)$ for the data collected at the Belmont and Ridgetown locations; the exceptions to this were harvest timing effects on grain yield at the Ridgetown locations $(P=0.616)$ and plant population effects on grain yield at the Belmont locations $(P=0.326)$. Significant harvest timing $\times$ management strategy interactions were also detected; accordingly, those and other interactions of interest [29] were explored.

\subsection{Harvest Timing and Hybrid Maturity Effects}

Full- and long-maturity hybrid yields were generally greater than the early-maturity hybrids (increases ranging from 2.6\% to 10.8\%), regardless of harvest timing (Table 4). These results from the autumn harvests were consistent with the previous research [1]-[3]; however, for autumn harvests at the Belmont locations, the greatest yield was recorded from the full-maturity hybrid $\left(12.2 \mathrm{Mg} \cdot \mathrm{ha}^{-1}\right)$ and there were no differences in yield between 
Table 2. Monthly rain and snow accumulation and the average monthly temperatures from May 2009 to May 2011 and the 30 year average monthly rain and snow accumulation and the 30-year average monthly temperatures ${ }^{\mathrm{a}}$.

\begin{tabular}{|c|c|c|c|c|c|c|c|c|c|c|c|c|}
\hline \multirow{2}{*}{ Month } & \multicolumn{3}{|c|}{2009} & \multicolumn{3}{|c|}{2010} & \multicolumn{3}{|c|}{2011} & \multicolumn{3}{|c|}{ 1981-2010 Average } \\
\hline & Rain & Snow & Temperature & Rain & Snow & Temperature & Rain & Snow & Temperature & Rain & Snow & Temperature \\
\hline & $\mathrm{mm}$ & $\mathrm{cm}$ & ${ }^{\circ} \mathrm{C}$ & $\mathrm{mm}$ & $\mathrm{cm}$ & ${ }^{\circ} \mathrm{C}$ & $\mathrm{mm}$ & $\mathrm{cm}$ & ${ }^{\circ} \mathrm{C}$ & $\mathrm{mm}$ & $\mathrm{cm}$ & ${ }^{\circ} \mathrm{C}$ \\
\hline January & & & & 14 & 37 & -5.7 & 9 & 58 & -7.8 & 33 & 49 & -5.6 \\
\hline February & & & & 0 & 43 & -4.6 & 22 & 79 & -6.2 & 34 & 38 & -4.5 \\
\hline March & & & & 37 & 2 & 3.5 & 87 & 49 & -1.3 & 46 & 29 & -0.1 \\
\hline April & & & & 87 & 1 & 10.1 & 107 & 20 & 7.0 & 75 & 9 & 6.8 \\
\hline May & 138 & 0 & 13.0 & 125 & 0 & 15.2 & 146 & 0 & 14.5 & 89 & 0 & 13.1 \\
\hline June & 131 & 0 & 17.5 & 106 & 0 & 19.1 & & & & 92 & 0 & 18.3 \\
\hline July & 108 & 0 & 18.3 & 84 & 0 & 22.0 & & & & 83 & 0 & 20.8 \\
\hline August & 100 & 0 & 19.7 & 55 & 0 & 21.7 & & & & 83 & 0 & 19.7 \\
\hline September & 58 & 0 & 16.2 & 88 & 0 & 15.9 & & & & 103 & 0 & 15.5 \\
\hline October & 85 & 0 & 8.3 & 101 & 0 & 10.3 & & & & 78 & 0 & 9.2 \\
\hline November & 37 & 5 & 6.1 & 92 & 6 & 4.2 & & & & 83 & 17 & 3.4 \\
\hline December & 58 & 32 & -2.6 & 8 & 109 & -5.0 & & & & 47 & 48 & -2.6 \\
\hline
\end{tabular}

${ }^{\mathrm{a}}$ Data sourced from an Environment Canada weather station located at the London International Airport (N 4301'59" W 8109'4"), London, Ontario, Canada.

Table 3. Partial ANOVA for grain yield, harvest moisture, test weight, stalk lodging, and stay-green of corn at experiments initiated in 2009 and 2010 at two locations in Ontario, Canada.

\begin{tabular}{|c|c|c|c|c|c|c|c|c|c|c|}
\hline \multirow{2}{*}{$\begin{array}{l}\text { Source of } \\
\text { variation }\end{array}$} & \multicolumn{2}{|c|}{ Grain yield } & \multicolumn{2}{|c|}{ Harvest moisture } & \multicolumn{2}{|c|}{ Test weight } & \multicolumn{2}{|c|}{ Stalk lodging } & \multicolumn{2}{|c|}{ Stay-green } \\
\hline & Belmont & Ridgetown & Belmont & Ridgetown & Belmont & Ridgetown & Belmont & Ridgetown & Belmont & Ridgetown \\
\hline & \multicolumn{10}{|c|}{$P$-value ${ }^{\mathrm{a}}$} \\
\hline $\begin{array}{l}\text { Harvest timing } \\
\text { (T) }\end{array}$ & $<0.001$ & 0.616 & $<0.001$ & $<0.001$ & 0.513 & 0.959 & . & . & 0.498 & 0.978 \\
\hline Population (P) & 0.326 & $<0.001$ & 0.609 & 0.016 & 0.023 & 0.033 & $<0.001$ & 0.030 & 0.285 & 0.003 \\
\hline Fungicide (F) & $<0.001$ & $<0.001$ & 0.529 & 0.375 & 0.885 & 0.004 & 0.001 & 0.431 & $<0.001$ & $<0.001$ \\
\hline Hybrid (H) & $<0.001$ & $<0.001$ & $<0.001$ & $<0.001$ & $<0.001$ & $<0.001$ & $<0.001$ & $<0.001$ & $<0.001$ & $<0.001$ \\
\hline $\mathrm{T} \times \mathrm{P}$ & 0.001 & 0.821 & 0.045 & 0.031 & 0.058 & 0.052 & . & . & 0.109 & 0.891 \\
\hline $\mathrm{T} \times \mathrm{F}$ & 0.041 & 0.512 & 0.431 & 0.141 & 0.509 & 0.081 & . & . & 0.697 & 0.646 \\
\hline $\mathrm{T} \times \mathrm{H}$ & 0.001 & 0.168 & $<0.001$ & $<0.001$ & 0.524 & 0.230 & . & . & 0.985 & 0.728 \\
\hline $\mathrm{P} \times \mathrm{F}$ & 0.225 & 0.328 & 0.469 & 0.590 & 0.571 & 0.796 & 0.455 & 0.083 & 0.083 & 1.000 \\
\hline $\mathrm{P} \times \mathrm{H}$ & 0.024 & 0.035 & 0.811 & 0.908 & 0.976 & 0.003 & 0.559 & 0.245 & 0.840 & 0.429 \\
\hline $\mathrm{F} \times \mathrm{H}$ & 0.018 & 0.411 & 0.542 & 0.565 & 0.198 & 0.394 & 0.676 & 0.685 & 0.723 & 0.486 \\
\hline $\mathrm{T} \times \mathrm{P} \times \mathrm{F}$ & 0.158 & 0.751 & 0.832 & 0.210 & 0.681 & 0.812 & . & . & 0.664 & 0.361 \\
\hline $\mathrm{T} \times \mathrm{P} \times \mathrm{H}$ & 0.326 & 0.998 & 0.927 & 0.767 & 0.473 & 0.689 & . & . & 0.298 & 0.753 \\
\hline $\mathrm{P} \times \mathrm{F} \times \mathrm{H}$ & 0.527 & 0.420 & 0.909 & 0.846 & 0.377 & 0.300 & 0.899 & 0.215 & 0.367 & 0.123 \\
\hline $\mathrm{T} \times \mathrm{P} \times \mathrm{F} \times \mathrm{H}$ & 0.445 & 0.394 & 0.982 & 0.970 & 0.173 & 0.460 & . & . & 0.721 & 0.507 \\
\hline
\end{tabular}

${ }^{\mathrm{a}}$ For convenience, $P$-values $<0.05$ are indicated in bold. 
Table 4. Harvest timing $\times$ hybrid maturity interactions on grain yield, moisture, and test weight and the hybrid maturity main effects on stay-green in autumn and lodging in spring and for experiments initiated in 2009 and 2010 at two locations in Ontario, Canada.

\begin{tabular}{|c|c|c|c|c|c|c|}
\hline \multirow[t]{2}{*}{ Parameter } & \multirow[t]{2}{*}{ Location } & \multirow[t]{2}{*}{ Timing } & \multicolumn{3}{|c|}{ Hybrid Adapted Maturity ${ }^{a}$} & \multirow[t]{2}{*}{$P$-value } \\
\hline & & & Early & Full & Long & \\
\hline & & & & $\mathrm{Mg} \cdot \mathrm{ha}$ & & \\
\hline \multirow[t]{5}{*}{ Grain yield } & Belmont & Autumn & $11.7 \mathrm{~b}$ & $12.2 \mathrm{a}$ & $11.8 b$ & $<0.001$ \\
\hline & & Spring & $9.1 \mathrm{~b}$ & $9.9 \mathrm{a}$ & $10.2 \mathrm{a}$ & $<0.001$ \\
\hline & Ridgetown & Autumn & $11.1 \mathrm{~b}$ & $11.4 \mathrm{a}$ & $11.5 \mathrm{a}$ & 0.023 \\
\hline & & Spring & $10.8 b$ & 11.3a & 11.3a & $<0.001$ \\
\hline & & & & $\%$ & & \\
\hline \multirow[t]{5}{*}{ Moisture } & Belmont & Autumn & $19.0 \mathrm{~b}$ & $19.4 b$ & $22.0 \mathrm{a}$ & $<0.001$ \\
\hline & & Spring & $13.0 \mathrm{a}$ & $12.6 \mathrm{a}$ & $12.1 \mathrm{~b}$ & $<0.001$ \\
\hline & Ridgetown & Autumn & $20.0 \mathrm{c}$ & $20.6 b$ & $22.4 a$ & $<0.001$ \\
\hline & & Spring & 13.4 & 13.7 & 13.3 & 0.074 \\
\hline & & & & $\mathrm{kg} \cdot \mathrm{hL}$ & & \\
\hline \multirow[t]{5}{*}{ Test weight } & Belmont & Autumn & 73.9a & $70.6 b$ & $69.6 c$ & $<0.001$ \\
\hline & & Spring & $71.5 \mathrm{a}$ & $69.1 \mathrm{~b}$ & $68.1 \mathrm{c}$ & $<0.001$ \\
\hline & Ridgetown & Autumn & $73.9 b$ & $75.4 \mathrm{a}$ & 72.2c & $<0.001$ \\
\hline & & Spring & $73.5 b$ & $75.1 \mathrm{a}$ & $72.5 \mathrm{c}$ & $<0.001$ \\
\hline & & & & $\%$ & & \\
\hline \multirow[t]{2}{*}{ Stay-green ${ }^{\text {cd }}$} & Belmont & Autumn & $3.5 \mathrm{c}$ & $5.1 \mathrm{~b}$ & $9.5 a$ & \\
\hline & Ridgetown & Autumn & $4.8 \mathrm{c}$ & $9.6 \mathrm{~b}$ & $19.1 \mathrm{a}$ & \\
\hline \multirow[t]{2}{*}{ Lodging $^{\mathrm{d}}$} & Belmont & Spring & 62.9a & $60.0 \mathrm{a}$ & $50.5 b$ & \\
\hline & Ridgetown & Spring & $32.4 \mathrm{a}$ & $25.1 b$ & $31.9 \mathrm{a}$ & \\
\hline
\end{tabular}

${ }^{\mathrm{a}}$ Means followed by the same letter within a row are not significantly different according to Fisher's Protected LSD ( $\left.P=0.05\right)$. ${ }^{\mathrm{b}}$ The SLICE option in PROC MIXED [29] partitioned interactions across harvest timing treatments and $P$-values indicate significance (Fisher's Protected LSD at $P=0.05$ ) within the slice. ${ }^{\mathrm{C}}$ Data were pooled across autumn and spring harvest timing treatments within a location. ${ }^{\mathrm{d}} \mathrm{P}$-values for stay-green and lodging main effects are reported in Table 3.

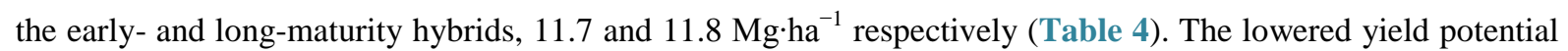
of the long-maturity hybrid was likely due to the growing conditions in 2009. That year at Belmont, hail destroyed approximately $50 \%$ of the leaf area at the VT growth stage; in addition, the long-maturity hybrid may not have had sufficient time to reach physiological maturity before a killing frost (data not shown). The autumn yield responses of the long-maturity hybrid at the Belmont locations likely contributed to a harvest timing $\times$ hybrid interaction ( $P=0.001$, Table 3 ). When the hybrids were overwintered at the Belmont locations, spring harvest losses increased from $13.4 \%$ to $21.7 \%$ as maturity ratings of the hybrids decreased from long- to early-maturity (Table 4). Conversely, at the Ridgetown locations no harvest timing $\times$ hybrid interaction was detected ( $P=0.168$, Table 3$)$, indicating that yield losses were minimal $(1.0 \%$ to $2.4 \%)$ regardless of maturity when corn was harvested in spring (Table 4).

While long-maturity hybrids tended to have increased yields, long-maturity hybrids also had the highest grain moistures in autumn and lowest test weights in autumn and spring. Grain moisture in autumn for the long-maturity hybrid was greater than both the early- and full-maturity hybrids with $22.0 \%$ and $22.4 \%$ at the Belmont and Ridgetown locations, respectively (Table 4). Compared to the grain harvested in autumn, grain 
moistures of overwintered corn were quite low, ranging from $12.1 \%$ to $13.7 \%$ in spring, regardless of hybrid maturity or location (Table 4), consistent with a comparable study [9]. Corn grain with higher moisture is often associated with lower test weight at harvest [9]. In the current study, early- and full-maturity hybrids consistently produced grain with greater test weights than long-maturity hybrids regardless of harvest timing. For example, at the Belmont locations, grain from long-maturity hybrids had test weights of 69.6 and $68.1 \mathrm{~kg} \cdot \mathrm{hL}^{-1} \mathrm{for}$ the harvests in autumn and spring, respectively (Table 4). In a Wisconsin study, similarly low test weights were reported for overwintered corn [9]. However, contrary to that study, grain test weights in spring increased as maturity decreased, especially for the full-maturity hybrid at the Ridgetown locations (Table 4), indicating that grain quality was preserved.

Full- and long-maturity hybrids maintained greater green leaf area percentages (stay-green) in September and generally had lower lodging percentages in spring. As would be expected, at both the Belmont and Ridgetown locations, stay-green increased with increasing maturity, with as much as $19 \%$ of the leaf area remaining green for the long-maturity hybrid in September at Ridgetown (Table 4). While stay-green responded similarly to hybrid maturity, the overall lodging percentages differed between the Belmont and Ridgetown locations and among the hybrids within locations. For example, spring lodging percentages ranged from 50.5\% to $62.9 \%$ at the Belmont locations and $25.1 \%$ to $32.4 \%$ at the Ridgetown locations (Table 4), consistent with a study that showed that hybrids can exhibit a lower level of lodging (39\%) at one location and a higher level (60\% to 65\%) at another during a delayed harvest [7]. Within locations, lodging tended to be greater for the early-maturity hybrid and the full- and long-maturity hybrid had the lowest lodging percentage at the Ridgetown and Belmont locations, respectively (Table 4).

\subsection{Harvest Timing and Plant Population Effects}

When plant populations were reduced from 80,000 down to 60,000 plants ha $^{-1}$, there was a $6 \%$ to $6.5 \%$ reduction in yield for the autumn harvests at the Belmont and Ridgetown locations and for the spring harvest at the Ridgetown locations; however, at the Belmont locations, grain yields in the spring increased 5\% as plant population decreased (Table 5). An overall yield reduction in response to a reduced plant population was consistent with the literature [1] [3] [10] [13] [30] [31]. Yet in this study, a significant harvest timing $\times$ plant population interaction was detected at the Belmont locations $(P=0.001$, Table 3$)$ primarily because corn yield increased from $9.5 \mathrm{Mg} \cdot \mathrm{ha}^{-1}$ at the 80,000 plants $\cdot \mathrm{ha}^{-1}$ population to $10.0 \mathrm{Mg} \cdot \mathrm{ha}^{-1}$ at the 60,000 plants $\cdot \mathrm{ha}^{-1}$ population (Table 5). This meant that the use of a lowered plant population reduced yield losses from overwintering corn; compared to the autumn harvests, yield losses for corn grown at 80,000 plants ha $^{-1}$ was $22.8 \%$ when harvested in the spring and $13 \%$ for corn at 60,000 plants $\cdot \mathrm{ha}^{-1}$ (Table 5). Conversely, there was no harvest timing $\times$ plant population interaction at Ridgetown ( $P=0.821$, Table 3 ) as less than $2 \%$ of the yield was lost from overwintering corn, regardless of plant population (Table 5). Consequently, when using standard production practices (plant population of 80,000 plants ha $^{-1}$ and an autumn harvest) compared to managing the crop to harvest in spring, there was only a 7.7\% yield loss at Ridgetown (11.7 vs. $10.8 \mathrm{Mg} \cdot \mathrm{ha}^{-1}$, Table 5), consistent with other research [9].

At both locations, grain moisture in autumn and grain test weight in spring tended to increase as plant populations decreased. At the Ridgetown locations, grain moisture in autumn increased negligibly (from 20.6\% to 21.3\%) as plant population decreased (Table 5), similar to other research [31]. Grain moisture in autumn responded similarly at the Belmont locations, but there was no statistical difference $(P=0.074$, Table 5$)$. For grain test weight, contrary to one study [31] but consistent with another [32], this parameter tended to increase as plant population decreased (Table 5). However, the test weight responses to a reduced plant population were only detected when corn was harvested in spring, unlike other studies using an autumn harvest [31] [32], which could indicate that the use of the 60,000 plants $\cdot$ ha $^{-1}$ plant population preserved grain quality.

Corn grown at 60,000 plants $\cdot \mathrm{ha}^{-1}$ generally had lower stay-green in autumn and substantially less lodging in spring after overwintering than corn grown at 80,000 plants $\cdot \mathrm{ha}^{-1}$. At the Ridgetown locations, $10.1 \%$ of the leaf area remained green in September compared to $12.2 \%$ for corn grown at 60,000 and 80,000 plants·ha ${ }^{-1}$ populations, respectively (Table 5). Whereas, at the Belmont locations, stay-green was not affected by plant population ( $P=0.285$, Table 3). For lodging ratings in spring, the proportion of corn lodged after overwintering at the 80,000 plants $\cdot$ ha $^{-1}$ population was $42.3 \%$ to $67.4 \%$ and lodging was reduced to $16.7 \%$ to $49.7 \%$ at the 60,000 plants $\cdot \mathrm{ha}^{-1}$ population for the Ridgetown and Belmont locations, respectively (Table 5). The overall reduction in 
Table 5. Harvest timing $\times$ plant population interactions on grain yield, moisture, and test weight and plant population main effects on stay-green in autumn and lodging in spring for experiments initiated in 2009 and 2010 at two locations in Ontario, Canada.

\begin{tabular}{|c|c|c|c|c|c|}
\hline \multirow[t]{2}{*}{ Parameter } & \multirow[t]{2}{*}{ Location } & \multirow[t]{2}{*}{ Timing } & \multicolumn{2}{|c|}{ Plant population (plants'ha $\left.{ }^{-1}\right)^{\mathrm{a}}$} & \multirow[t]{2}{*}{$P$-value ${ }^{\mathrm{b}}$} \\
\hline & & & 60,000 & 80,000 & \\
\hline & & \multicolumn{4}{|c|}{$\mathrm{Mg} \cdot \mathrm{ha}^{-1}$} \\
\hline \multirow[t]{5}{*}{ Grain yield } & Belmont & Autumn & $11.5 b$ & $12.3 \mathrm{a}$ & 0.014 \\
\hline & & Spring & $10.0 \mathrm{a}$ & $9.5 b$ & 0.035 \\
\hline & Ridgetown & Autumn & $11.0 \mathrm{~b}$ & $11.7 \mathrm{a}$ & 0.005 \\
\hline & & Spring & $10.8 b$ & $11.5 \mathrm{a}$ & 0.002 \\
\hline & & \multicolumn{4}{|c|}{$\%$} \\
\hline \multirow[t]{5}{*}{ Moisture } & Belmont & Autumn & 20.5 & 19.8 & 0.074 \\
\hline & & Spring & 12.4 & 12.7 & 0.225 \\
\hline & Ridgetown & Autumn & 21.3a & $20.6 b$ & 0.003 \\
\hline & & Spring & 13.4 & 13.4 & 0.817 \\
\hline & & \multicolumn{4}{|c|}{$\mathrm{kg} \cdot \mathrm{hL}^{-1}$} \\
\hline \multirow[t]{5}{*}{ Test weight } & Belmont & Autumn & 71.8 & 71.4 & 0.715 \\
\hline & & Spring & $70.3 a$ & $69.1 \mathrm{~b}$ & 0.005 \\
\hline & Ridgetown & Autumn & 73.9 & 73.8 & 0.857 \\
\hline & & Spring & $74.2 \mathrm{a}$ & $73.3 b$ & 0.006 \\
\hline & & \multicolumn{4}{|c|}{$\%$} \\
\hline \multirow[t]{2}{*}{ Stay-green $^{\text {cd }}$} & Belmont & Autumn & 5.8 & 6.3 & \\
\hline & Ridgetown & Autumn & $10.1 \mathrm{~b}$ & $12.2 \mathrm{a}$ & \\
\hline \multirow[t]{2}{*}{ Lodging $^{\mathrm{d}}$} & Belmont & Spring & $49.7 \mathrm{~b}$ & $67.4 \mathrm{a}$ & \\
\hline & Ridgetown & Spring & $16.7 \mathrm{~b}$ & 42.3a & \\
\hline
\end{tabular}

${ }^{\mathrm{a}}$ Means followed by the same letter within a row are not significantly different according to Fisher's Protected LSD ( $\left.P=0.05\right)$. ${ }^{\mathrm{b}}$ The SLICE option in PROC MIXED [29] partitioned interactions across harvest timing treatments and $P$-values indicate significance (Fisher's Protected LSD at $P=0.05$ ) within the slice. ${ }^{\mathrm{C}}$ Data were pooled across autumn and spring harvest timing treatments within a location. ${ }^{\mathrm{d}} \mathrm{P}$-values for stay-green and lodging main effects are reported in Table 3.

lodging with the use of a lowered plant population was consistent with reports on a study where the harvest was delayed until early to mid-December [7] or late March [8].

\subsection{Harvest Timing and Fungicide Application Effects}

Compared to untreated plants, corn that received 200 g a.i. ha ${ }^{-1}$ of QUILT $^{\circledR}$ fungicide (azoxystrobin + propiconazole) at the VT to R1 growth stage had increased yields regardless of harvest timing. Depending on location, the fungicide application contributed to a $3.3 \%$ to $3.5 \%$ and $4.4 \%$ to $6.9 \%$ yield increase for the autumn and spring harvest, respectively (Table 6). In the literature, strobilurin (e.g., azoxystrobin) fungicide application has been associated with increased yields [33], but generally not in corn when disease severity is low [16] [34]-[37]. In this study, foliar disease severity was relatively low across in all location-years, with severity visually rated at less than 5\% coverage of leaf tissue in September (data not shown). The yield response to a fungicide application depended on harvest timing; thus, a significant harvest timing $\times$ fungicide application interaction was detected at the Belmont locations $(P=0.041)$, but not at the Ridgetown locations $(P=0.512$, Table 3$)$. For example, less than $2 \%$ of the yield was lost from overwintering corn at Ridgetown, regardless of fun- 
Table 6. Harvest timing $\times$ QUILT $^{\circledR}$ fungicide (azoxystrobin + propiconazole) interactions on grain yield, moisture, and test weight and fungicide main effects on stay-green in autumn and lodging in spring for experiments initiated in 2009 and 2010 at two locations in Ontario, Canada.

\begin{tabular}{|c|c|c|c|c|c|}
\hline \multirow[t]{2}{*}{ Parameter } & \multirow[t]{2}{*}{ Location } & \multirow[t]{2}{*}{ Timing } & \multicolumn{2}{|c|}{$\begin{array}{l}\text { Azoxystrobin }+ \text { propiconazole } \\
\qquad\left(\text { g a.i. ha }{ }^{-1}\right)^{\mathrm{a}}\end{array}$} & \multirow[t]{2}{*}{$P$-value } \\
\hline & & & 0 & 200 & \\
\hline & & \multicolumn{4}{|c|}{$\mathrm{Mg} \cdot \mathrm{ha}^{-1}$} \\
\hline \multirow[t]{5}{*}{ Grain yield } & Belmont & Autumn & $11.7 \mathrm{~b}$ & $12.1 \mathrm{a}$ & 0.019 \\
\hline & & Spring & $9.4 \mathrm{~b}$ & $10.1 \mathrm{a}$ & $<0.001$ \\
\hline & Ridgetown & Autumn & $11.1 \mathrm{~b}$ & $11.5 \mathrm{a}$ & 0.003 \\
\hline & & Spring & $10.9 \mathrm{~b}$ & $11.4 \mathrm{a}$ & $<0.001$ \\
\hline & & \multicolumn{4}{|c|}{$\%$} \\
\hline \multirow[t]{5}{*}{ Moisture } & Belmont & Autumn & 20.1 & 20.2 & 0.911 \\
\hline & & Spring & 12.6 & 12.5 & 0.316 \\
\hline & Ridgetown & Autumn & 21.1 & 20.8 & 0.106 \\
\hline & & Spring & 13.4 & 13.5 & 0.668 \\
\hline & & \multicolumn{4}{|c|}{$\mathrm{kg} \cdot \mathrm{hL}^{-1}$} \\
\hline \multirow[t]{5}{*}{ Test weight } & Belmont & Autumn & 71.6 & 71.5 & 0.715 \\
\hline & & Spring & 69.7 & 69.7 & 0.569 \\
\hline & Ridgetown & Autumn & $73.4 \mathrm{~b}$ & 74.3a & 0.002 \\
\hline & & Spring & 73.7 & 73.9 & 0.370 \\
\hline & & \multicolumn{4}{|c|}{$\%$} \\
\hline \multirow[t]{2}{*}{ Stay-green ${ }^{\text {cd }}$} & Belmont & Autumn & $4.8 \mathrm{~b}$ & 7.3a & \\
\hline & Ridgetown & Autumn & $9.6 \mathrm{~b}$ & $12.8 \mathrm{a}$ & \\
\hline \multirow[t]{2}{*}{ Lodging $^{\mathrm{d}}$} & Belmont & Spring & $65.0 \mathrm{a}$ & $52.0 \mathrm{~b}$ & \\
\hline & Ridgetown & Spring & 30.4 & 28.6 & \\
\hline
\end{tabular}

${ }^{\mathrm{a}}$ Means followed by the same letter within a row are not significantly different according to Fisher's Protected LSD ( $\left.P=0.05\right)$. ${ }^{\mathrm{b}}$ The SLICE option in PROC MIXED [29] partitioned interactions across harvest timing treatments and $P$-values indicate significance (Fisher's Protected LSD at $P=0.05$ ) within the slice. ${ }^{\mathrm{c}}$ Data were pooled across autumn and spring harvest timing treatments within a location. ${ }^{\mathrm{d}} P$-values for stay-green and lodging main effects are reported in Table 3.

gicide application. Whereas at Belmont, spring yield losses for corn that did not receive an application of fungicide was $19.7 \%$ (11.7 vs. $9.4 \mathrm{Mg} \cdot \mathrm{ha}^{-1}$ ) compared to $16.5 \%\left(12.1 \mathrm{vs.} 10.1 \mathrm{Mg} \cdot \mathrm{ha}^{-1}\right)$ for corn treated with fungicide (Table 6). Therefore, when comparing standard management practices (no unwarranted fungicide application and an autumn harvest) compared to managing the crop to harvest in spring, fungicide use reduced yield losses to an average of $13.7 \%$ (11.7 vs. $10.1 \mathrm{Mg} \cdot \mathrm{ha}^{-1}$ ) across locations at Belmont, and appeared to increase yields at the Ridgetown locations by an average of $2.6 \%$ (11.1 vs. $11.4 \mathrm{Mg} \cdot \mathrm{ha}^{-1}$, Table 6).

Fungicide application had no effect on grain moisture and had a minimal impact on test weight in autumn at the Ridgetown locations; but, fungicide application did have a considerable effect on stay-green (green leaf area increased in autumn) and lodging (lodging was reduced in spring). Grain moisture was not affected by fungicide application at either the Belmont $(P=0.529)$ or Ridgetown locations $(P=0.375$, Table 3$)$. Grain test weight negligibly increased with a fungicide application, but only at the Ridgetown locations in autumn (Table 6). However, compared to grain moisture and test weights, more notable effects were detected for stay-green and lodging. For example, corn plants treated with fungicide had a greater percentage of green leaf area at the autumn harvests at the Belmont (7.3\%) and Ridgetown locations (12.8\%) compared to untreated plants, 4.8\% and 
9.6\% respectively (Table 6). These observations were consistent with the stay-green "physiological effect" reported in corn and other crops following an application of a strobilurin fungicide [16] [17] [33]. Furthermore, at the Belmont locations, the proportion of corn lodged in spring that did not receive an application of fungicide was $65 \%$ and lodging percentage was reduced to $52 \%$ for plants that received fungicide (Table 6). Strobilurin fungicides have been shown to reduce stalk rot and improve corn stalk health [16] [17] [36]; but, to the best of our knowledge, this is the first documented instance of an autumn-applied fungicide that contributed to improved overwintering standability for plants harvested in spring.

\subsection{Management Strategy Combination to Overwinter Corn}

Across all hybrids, corn managed specifically for overwintering (plant population of 60,000 plants ha $^{-1}$ and a foliar fungicide application) had similar or greater spring yields than corn that was overwintered with the standard

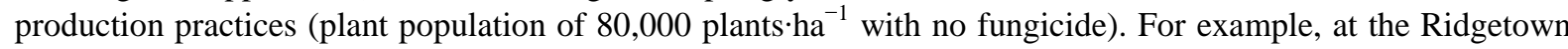
locations across all hybrids, there was no difference in yield between corn with the overwintering strategy and corn overwintered with the standard production practices (11.1 vs. $11.3 \mathrm{Mg} \cdot \mathrm{ha}^{-1}$, Table 7). Furthermore, yield losses at the Ridgetown locations were only $3.5 \%$ (11.1 vs. $\left.11.5 \mathrm{Mg} \cdot \mathrm{ha}^{-1}\right)$ across all hybrids when comparing the overwintering management strategy in a spring harvest to corn that was harvested in autumn managed using the

Table 7. Harvest timing $\times$ plant population $\times$ fungicide interactions on grain yield, moisture, and test weight and plant population $\times$ fungicide interactions on stay-green in autumn and lodging in spring for experiments initiated in 2009 and 2010 at two locations in Ontario, Canada.

\begin{tabular}{|c|c|c|c|c|c|c|c|}
\hline \multirow[t]{2}{*}{ Parameter } & \multirow[t]{2}{*}{ Location } & \multirow[t]{2}{*}{ Timing } & \multicolumn{4}{|c|}{ Management strategy ${ }^{\mathrm{ab}}$} & \multirow[t]{2}{*}{$P$-value ${ }^{\mathrm{c}}$} \\
\hline & & & $\begin{array}{l}\text { Low POP } \\
\text {-Fungicide }\end{array}$ & $\begin{array}{l}\text { Low POP } \\
\text { +Fungicide }\end{array}$ & $\begin{array}{c}\text { High POP } \\
\text {-Fungicide }\end{array}$ & $\begin{array}{l}\text { High POP } \\
\text { +Fungicide }\end{array}$ & \\
\hline & & \multicolumn{6}{|c|}{$\mathrm{Mg} \cdot \mathrm{ha}^{-1}$} \\
\hline \multirow[t]{5}{*}{ Grain yield } & Belmont & Autumn & $11.4 \mathrm{~b}$ & $11.7 \mathrm{~b}$ & $12.1 \mathrm{a}$ & $12.4 \mathrm{a}$ & 0.002 \\
\hline & & Spring & $9.5 b$ & $10.5 a$ & $9.3 b$ & $9.8 \mathrm{~b}$ & $<0.001$ \\
\hline & Ridgetown & Autumn & $10.8 \mathrm{c}$ & $11.2 \mathrm{~b}$ & $11.5 b$ & $11.8 \mathrm{a}$ & $<0.001$ \\
\hline & & Spring & $10.5 c$ & $11.1 \mathrm{~b}$ & $11.3 \mathrm{~b}$ & $11.7 \mathrm{a}$ & $<0.001$ \\
\hline & & \multicolumn{6}{|c|}{$\%$} \\
\hline \multirow[t]{5}{*}{ Moisture } & Belmont & Autumn & 20.5 & 20.5 & 19.8 & 19.9 & 0.288 \\
\hline & & Spring & 12.5 & 12.3 & 12.8 & 12.7 & 0.418 \\
\hline & Ridgetown & Autumn & $21.1 \mathrm{~b}$ & $21.6 \mathrm{a}$ & $20.6 b$ & $20.6 b$ & 0.002 \\
\hline & & Spring & 13.5 & 13.4 & 13.4 & 13.4 & 0.915 \\
\hline & & \multicolumn{6}{|c|}{$\mathrm{kg} \cdot \mathrm{hL}^{-1}$} \\
\hline \multirow[t]{5}{*}{ Test weight } & Belmont & Autumn & 71.9 & 71.6 & 71.3 & 71.5 & 0.859 \\
\hline & & Spring & $70.2 \mathrm{a}$ & $70.4 \mathrm{a}$ & $69.2 \mathrm{~b}$ & $69.1 \mathrm{~b}$ & 0.016 \\
\hline & Ridgetown & Autumn & $74.4 \mathrm{a}$ & 73.3c & $74.2 \mathrm{ab}$ & $73.5 \mathrm{bc}$ & 0.017 \\
\hline & & Spring & $74.5 \mathrm{a}$ & $74.0 \mathrm{ab}$ & $73.3 b$ & $73.4 \mathrm{~b}$ & 0.009 \\
\hline & & \multicolumn{6}{|c|}{$\%$} \\
\hline \multirow[t]{2}{*}{ Stay-green ${ }^{\text {de }}$} & Belmont & Autumn & 4.9 & 6.7 & 4.6 & 8.0 & \\
\hline & Ridgetown & Autumn & 8.5 & 11.7 & 10.6 & 13.8 & \\
\hline \multirow[t]{2}{*}{ Lodging $^{\mathrm{e}}$} & Belmont & Spring & 55.1 & 44.3 & 74.9 & 59.8 & \\
\hline & Ridgetown & Spring & 16.5 & 16.9 & 44.3 & 40.3 & \\
\hline
\end{tabular}

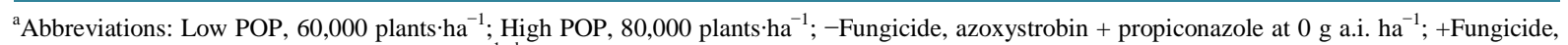
azoxystrobin + propiconazole at $200 \mathrm{~g}$ a.i. ha $^{-1}$. ${ }^{b}$ Means followed by the same letter within a row are not significantly different according to Fisher's Protected LSD $(P=0.05)$. ${ }^{\mathrm{c}}$ The SLICE option in PROC MIXED [29] partitioned interactions across harvest timing treatments and $P$-values indicate significance (Fisher's Protected LSD at $P=0.05$ ) within the slice. ${ }^{\mathrm{d}}$ Data were pooled across autumn and spring harvest timing treatments within a location. ${ }^{\mathrm{e}} \mathrm{P}$-values for stay-green and lodging main effects are reported in Table 3. 
standard production practices (Table 7). At the Belmont locations, yields for corn with the overwintering strategy were $11.4 \%$ greater (10.5 vs. $9.3 \mathrm{Mg} \cdot \mathrm{ha}^{-1}$ ) than corn that was overwintered using standard practices (Table 7). This meant that, compared to harvesting the crop in autumn with the standard management practices, there

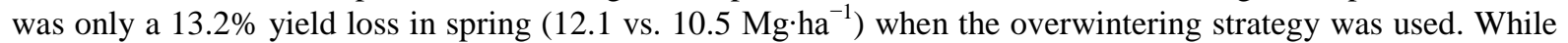
comparable studies on overwintering corn are limited, the yield losses observed in this study (3.5\% and 13.2\% for the Ridgetown and Belmont locations, respectively) were substantially lower than the $7 \%$ to $10 \%$ yield loss reported under favorable conditions and the $38 \%$ to $65 \%$ yield loss under less favorable overwintering conditions [9]. The results of the current study were more similar to $15 \%$ yield loss when a harvest was delayed until late March [8]; however, yield losses reported in that study represented only one site-year, contrary to this study.

While minimizing yield loss is an important overall goal for the development of an overwintering management strategy, the maintenance of grain quality is an important consideration as well. As such, grain test weights in spring across all hybrids tended to be lower for corn managed for overwintering than corn grown with standard production practices and harvested in autumn. However, grain test weights in spring for corn with the overwintering strategy were greater than or equal to corn overwintered with the standard practices. For example, grain test weights across all hybrids were generally lower in spring for corn with the overwintering strategy compared to harvesting in autumn using the standard production practice at the Belmont $\left(70.4 \mathrm{vs} .71 .3 \mathrm{~kg} \cdot \mathrm{hL} \mathrm{L}^{-1}\right)$ and Ridgetown (74.0 vs. $74.2 \mathrm{~kg} \cdot \mathrm{hL}^{-1}$ ) locations (Table 7). Yet, across all hybrids at the Belmont locations, corn harvested in spring with the overwintering strategy had a greater grain test weight than corn with standard production practices, 70.4 and $69.2 \mathrm{~kg} \cdot \mathrm{hL}^{-1}$ respectively (Table 7). At the Ridgetown locations, grain test weights in spring for corn with the overwintering strategy were numerically greater than corn managed with standard practices, but the differences were not statistically significant (Table 7). Grain test weights have been shown to decrease as corn overwinters [8] [9]. In the current study, when comparing grain test weights across management strategies within the spring harvest timings, the results indicate that test weight, a grain quality trait, was conserved. However, overwintering corn can also reduce the quality and value of harvested grain because of fungal infections [38]. There was some evidence of higher mycotoxin levels present in the corn harvested in spring, but this was not a grain quality parameter considered in this study.

\section{Conclusion}

Harvesting corn in spring is often considered when fields are inaccessible for a timely harvest, when grain moistures are excessively high (>30\% to 35\%) in autumn, when market prices are low, and/or when drying costs are high. Thus, there is a need for developing a strategy to minimize some of the risks associated with this practice. In this research, an overwintering management strategy for corn was identified which consisted of planting at a low plant population $\left(60,000\right.$ plants $\left.\cdot \mathrm{ha}^{-1}\right)$ and spraying the crop with a foliar fungicide around tasseling. This strategy minimized yield losses across all hybrids by $3.5 \%$ to $13.2 \%$ at four out of five field locations, through improvements on corn standability compared to when the crop was overwintered using a standard population with no fungicide application. In southern Ontario, the standard management practices for corn production consists of planting at a relatively high plant population $\left(80,000\right.$ plants $\left.^{-} \mathrm{ha}^{-1}\right)$, applying a foliar fungicide only if there is justifiable disease pressure, harvesting in the autumn when grain moisture is approximately $25 \%$ or less, and drying grain down to $15.5 \%$ using on-farm grain dryers or through commercial elevators. Unfortunately, while the overwintering management strategy was an improvement over previous reports of yield losses [8] [9], lodging was still unacceptable at most locations, with yield losses as high as $50 \%$ (estimated) at the Lucan location where $100 \%$ of the corn was lodged in spring. Furthermore, regardless of the management treatment, grain moistures in this study would likely have been too low for growers to economically justify forgoing the typical autumn harvest, especially if there are relatively low breakeven drying costs [38]. Further research in this area is warranted as a comprehensive economic analysis of the yield data in this study as affected by management strategy would still be of value to growers in the northern corn producing regions. In addition, the management of grain quality as affected by rot and mold after overwintering should be addressed in future research as well. However, based on the uncertainty of winter weather and impact on lodging and yield loss, harvesting corn in spring may still be too much of a high-risk practice to be widely accepted in areas where the winters are typically harsh, regardless of the management strategy deployed.

\section{Acknowledgements}

The authors would like to acknowledge the farmer cooperators who participated in this study; the technical as- 
sistance from Rob Templeman, Gerald Backx, Kevin Dufton, Jonathan Brinkman, and Peter Johnson; and the funding support from Grain Farmers of Ontario, Agricultural Adaptation Council through the Farm Innovation Program, and Syngenta Crop Protection for the fungicide and herbicides used in the study (Dr. Harold Wright).

\section{References}

[1] Roekel, R.J. and Coulter, J.A. (2012) Agronomic Responses of Corn Hybrid to Row Width and Plant Density. Agronomy Journal, 104, 612-620. http://dx.doi.org/10.2134/agronj2011.0380

[2] Capristo, P.R., Rizzalli, R.H. and Andrade, F.H. (2007) Ecophysiological Yield Components of Maize Hybrids with Contrasting Maturity. Agronomy Journal, 99, 1111-1118. http://dx.doi.org/10.2134/agronj2006.0360

[3] Farnham, D.E. (2001) Row Spacing, Plant Density, and Hybrid Effects on Corn Grain Yield and Moisture. Agronomy Journal, 93, 1049-1053. http://dx.doi.org/10.2134/agronj2001.9351049x

[4] Lauer, J.G., Carter, P.R., Wood, T.M., Diezel, G., Wiersma, D.W., Rand, R.E. and Mlynarek, M.J. (1999) Corn Hybrid Response to Planting Date in the Northern Corn Belt. Agronomy Journal, 91, 834-839. http://dx.doi.org/10.2134/agronj1999.915834x

[5] Henderson, K.G. and Shields, B.P. (2006) Characteristics of Autumn Precipitation Trends in the Northeastern United States. The Professional Geographer, 58, 184-196. http://dx.doi.org/10.1111/j.1467-9272.2006.00525.x

[6] Henderson, K.G. (2000) Autumn Precipitation Trends in the Northeastern United States. Middle States Geographer, 33, 74-81.

[7] Thomison, P.R., Mullen, R.W., Lipps, P.E., Doerge, T. and Geyer, A.B. (2011) Corn Response to Harvest Date as Affected by Plant Population and Hybrid. Agronomy Journal, 103, 1765-1772. http://dx.doi.org/10.2134/agronj2011.0147

[8] Thomison, P., Geyer, A. and Minyo, R. (2006) Leaving Corn in the Field Through the Winter: How Much Do You Lose? Crop Observation and Recommendation Network. http://corn.osu.edu/newsletters/2006/article?issueid=125\&articleid=717

[9] Lauer, J. (2004) Some Pros and Cons of Letting Corn Stand in the Field through Winter. Wisconsin Crop Manager. http://corn.agronomy.wisc.edu/WCM/W160.aspx

[10] Stanger, T.F. and Lauer, J.G. (2007) Corn Stalk Response to Plant Population and the Bt-European Corn Borer Trait. Agronomy Journal, 99, 657-664. http://dx.doi.org/10.2134/agronj2006.0079

[11] Stanger, T.F. and Lauer, J.G. (2006) Optimum Plant Population of Bt and Non-Bt Corn in Wisconsin. Agronomy Journal, 98, 914-921. http://dx.doi.org/10.2134/agronj2005.0144

[12] Bruns, H.A. and Abbas, H.K. (2005) Ultra-High Plant Populations and Nitrogen Fertility Effects on Corn in the Mississippi Valley. Agronomy Journal, 97, 1136-1140. http://dx.doi.org/10.2134/agronj2004.0295

[13] Pedersen, P. and Lauer, J.G. (2002) Influence of Rotation Sequence on the Optimum Corn and Soybean Plant Population. Agronomy Journal, 94, 968-974. http://dx.doi.org/10.2134/agronj2002.0968

[14] Thomison, P.R. and Jordan, D.M. (1995) Plant Population Effects on Corn Hybrids Differing in Ear Growth Habit and Prolificacy. Journal of Production Agriculture, 8, 394-400. http://dx.doi.org/10.2134/jpa1995.0394

[15] Moentono, M.D., Darrah, L.L., Zuber, M.S. and Krause, G.F. (1984) Effects of Selection for Stalk Strength on Responses to Plant Density and Level of Nitrogen Application in Maize. Maydica, 29, 431-452.

[16] Byamukama, E., Abendroth, L.J., Elmore, R.W. and Robertson, A.E. (2013) Quantifying the Effect of Pyraclostrobin on Grain-fill Period and Kernel Dry Matter Accumulation in Maize. Plant Health Progress. http://dx.doi.org/10.1094/PHP-2013-1024-02-RS

[17] Wise, K. and Mueller, D. (2011) Are Fungicides No Longer Just for Fungi? An Analysis of Foliar Fungicide Use in Corn. APSnet Features. http://dx.doi.org/10.1094/APSnetFeature-2011-0531

[18] Mahoney, K.J., Nurse, R.E., Everman, W.J., Sprague, C.L. and Sikkema, P.H. (2014) Tolerance of Corn (Zea mays L.) to Early and Late Glyphosate Applications. American Journal of Plant Science, 5, 2748-2754. http://dx.doi.org/10.4236/ajps.2014.518291

[19] US Department of Agriculture-Economic Research Service (2014) Adoption of Genetically Engineered Crops in the U.S.

http://www.ers.usda.gov/data-products/adoption-of-genetically-engineered-crops-in-the-us/recent-trends-in-ge-adoptio $\underline{\mathrm{n}}$

[20] Soltani, N., Stewart, C.L., Nurse, R.E., Van Eerd, L.L., Vyn, R.J. and Sikkema, P.H. (2012) Weed Control, Environmental Impact and Profitability of Weed Management Strategies in Glyphosate-Resistant Corn. American Journal of Plant Science, 3, 1594-1607. http://dx.doi.org/10.4236/ajps.2012.311193

[21] Ma, B.L., Meloche, F. and Wei, L. (2009) Agronomic Assessment of Bt Trait and Seed or Soil-Applied Insecticides on 
the Control of Corn Rootworm and Yield. Field Crops Research, 111, 189-196. http://dx.doi.org/10.1016/j.fcr.2008.12.006

[22] Gray, M.E., Steffey, K.L., Estes, R.E. and Schroeder, J.B. (2007) Responses of Transgenic Maize Hybrids to Variant Western Corn Rootworm Larval Injury. Journal of Applied Entomology, 131, 386-390. http://dx.doi.org/10.1111/j.1439-0418.2007.01171.x

[23] Graeber, J.V., Nafziger, E.D. and Mies, D.W. (1999) Evaluation of Transgenic, Bt-Containing Corn Hybrids. Journal of Production Agriculture, 12, 659-663. http://dx.doi.org/10.2134/jpa1999.0659

[24] Lauer, J.G. and Wedberg, J. (1999) Grain Yield of Initial Bt Corn Hybrid Introductions to Farmers in the Northern Corn Belt. Journal of Production Agriculture, 12, 373-376. http://dx.doi.org/10.2134/jpa1999.0373

[25] Rodgers, E.G. (1952) Brittleness and Other Responses of Corn to 2,4-Dichlorophenoxyacetic Acid. Plant Physiology, 27, 153-172. http://dx.doi.org/10.1104/pp.27.1.153

[26] Vyn, J.D., Swanton, C.J., Weaver, S.E. and Sikkema, P.H. (2006) Control of Amaranthus tuberculatus var. rudis (Common Waterhemp) with Pre and Post-Emergence Herbicides in Zea mays L. (Maize). Crop Protection, 25, 10511056. http://dx.doi.org/10.1016/j.cropro.2006.01.016

[27] Brown, D.M. and Bootsma, A. (1993) Crop Heat Units for Corn and Other Warm-Season Crops in Ontario. Ontario Ministry of Agriculture and Food, Toronto. Factsheet No. 93-119, Agdex 111/31, 4 p.

[28] Ontario Ministry of Agriculture and Food and Ministry of Rural Affairs (2013) Guide to Weed Control, 2014-2015. Publication 75, Toronto, 432 p.

[29] Littell, R.C. (2006) SAS ${ }^{\circledR}$ For Mixed Models. 2nd Edition, SAS Institute Inc., Cary, 813 p.

[30] Coulter, J.A., Nafziger, E.D., Janssen, M.R. and Pedersen, P. (2010) Response of Bt and Near-Isoline Corn Hybrids to Plant Density. Agronomy Journal, 102, 103-111. http://dx.doi.org/10.2134/agronj2009.0217

[31] Widdicombe, W.D. and Thelen, K.D. (2002) Row Width and Plant Density Effects on Corn Grain Production in the Northern Corn Belt. Agronomy Journal, 94, 1020-1023. http://dx.doi.org/10.2134/agronj2002.1020

[32] Porter, P.M., Hicks, D.R., Lueschen, W.E., Ford, J.H., Warnes, D.D. and Hoverstad, T.R. (1997) Corn Response to Row Width and Plant Population in the Northern Corn Belt. Journal of Production Agriculture, 10, 293-300. http://dx.doi.org/10.2134/jpa1997.0293

[33] Bartlett, D.W., Clough, J.M., Godwin, J.R., Hall, A.A., Hamer, M. and Parr-Dobrzanski, B. (2002) The Strobilurin Fungicides. Pest Management Science, 58, 649-662. http://dx.doi.org/10.1002/ps.520

[34] Blandino, M., Galeazzi, M., Savoia, W. and Reyneri, A. (2012) Timing of Azoxystrobin + Propiconazole Application on Maize to Control Northern Corn Leaf Blight and Maximize Grain Yield. Field Crops Research, 139, 20-29. http://dx.doi.org/10.1016/j.fcr.2012.09.014

[35] Bradley, C.A. and Ames, K.A. (2010) Effect of Foliar Fungicides on Corn with Simulated Hail Damage. Plant Disease, 94, 83-86. http://dx.doi.org/10.1094/PDIS-94-1-0083

[36] Nelson, K.A. and Meinhardt, C.G. (2011) Foliar Boron and Pyraclostrobin Effects on Corn Yield. Agronomy Journal, 103, 1352-1358. http://dx.doi.org/10.2134/agronj2011.0090

[37] Shah, D.A. and Dillard, H.R. (2010) Managing Foliar Diseases of Processing Sweet Corn in New York with Strobilurin Fungicides. Plant Disease, 94, 213-220. http://dx.doi.org/10.1094/PDIS-94-2-0213

[38] Schneider, N. and Lauer, J. (2009) Weigh Risk of Leaving Corn Stand Through Winter. UW-Extension, Team Grains. http://corn.agronomy.wisc.edu/Teams/TG001.pdf 
Scientific Research Publishing (SCIRP) is one of the largest Open Access journal publishers. It is currently publishing more than 200 open access, online, peer-reviewed journals covering a wide range of academic disciplines. SCIRP serves the worldwide academic communities and contributes to the progress and application of science with its publication.

Other selected journals from SCIRP are listed as below. Submit your manuscript to us via either submit@scirp.org or Online Submission Portal.
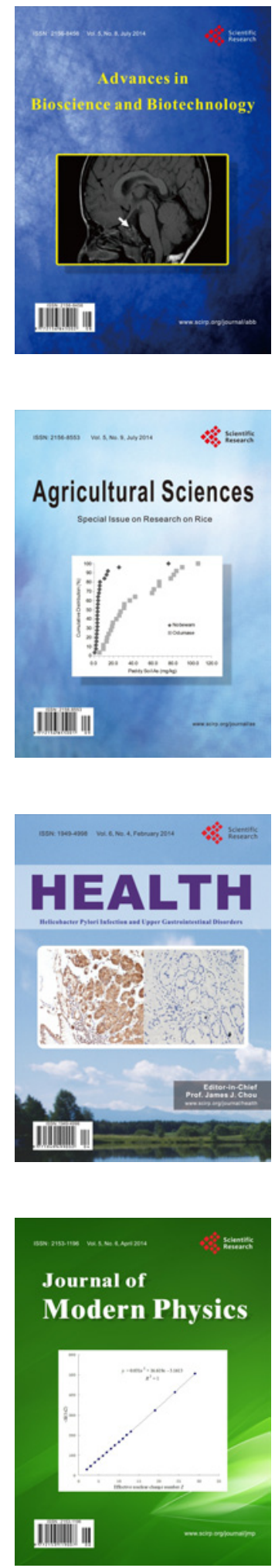
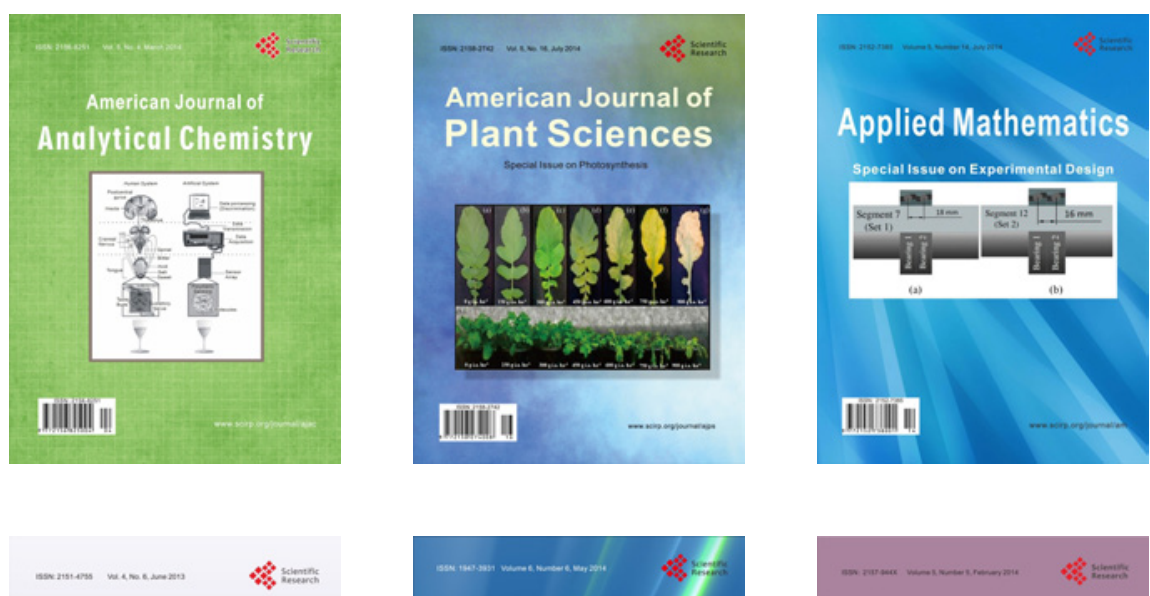

Creative Education
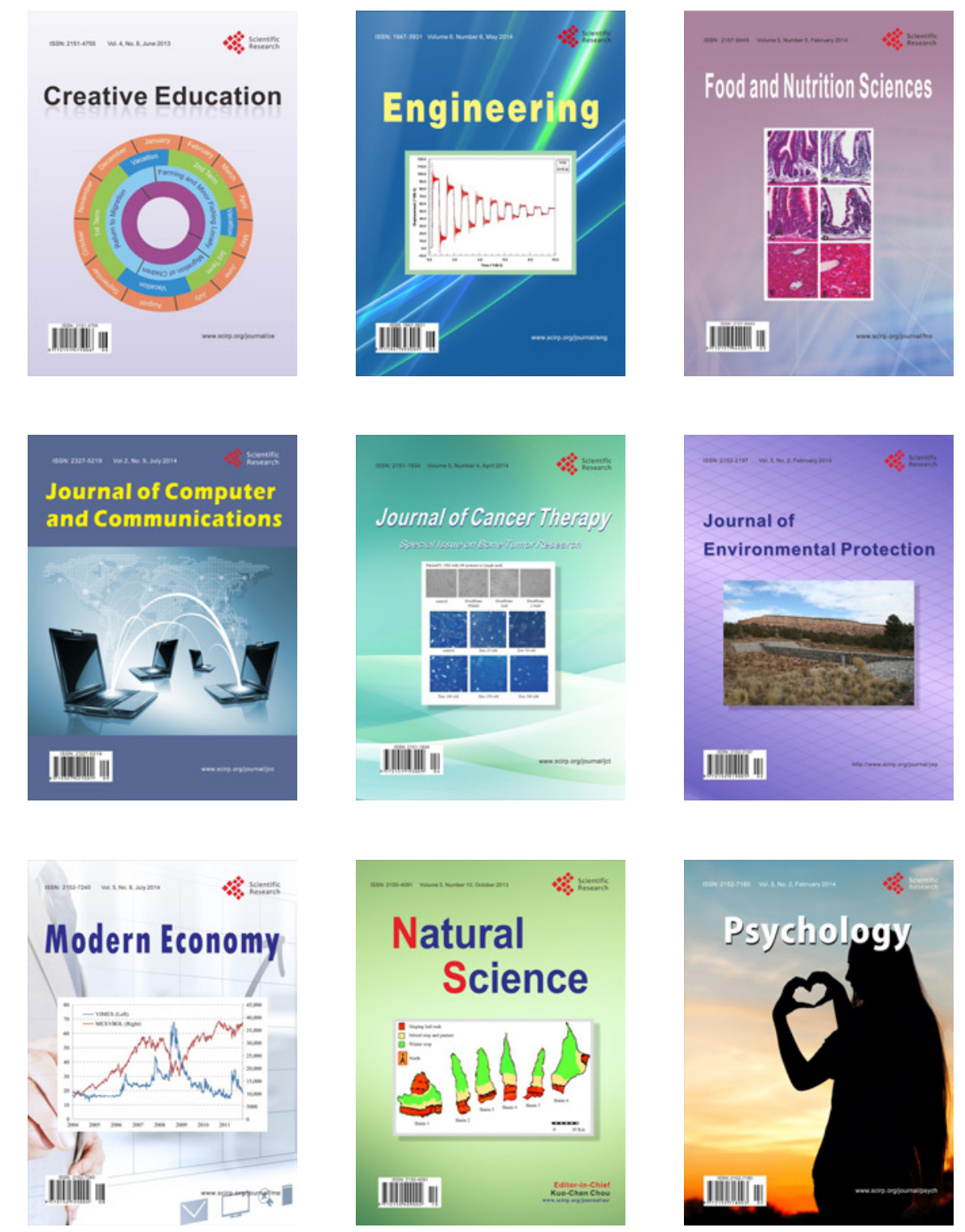